\title{
STRATIGRAPHIC CLASSIFICATION IN PRE-CAMBRIAN ROCKS
}

SIR,-Dr. Allen's and Dr. Reedman's proposal (Geol. Mag., 105, (3), 290-297, 1968) that the term 'orogenic complex' should be given to 'the complete suite of rocks of the orogenic belt' (p.293) will be welcomed by geologists working in the African metamorphic Pre-Cambrian terrains. It will be the more readily accepted since there is a terminological gap to be filled and because its necessity has been tacitly understood, or as the authors say 'the scheme has been intuitively employed by geologists in Africa for at least a decade'. Sutton \& Watson (1951), in one of the fundamental texts of 'basement' geology from which much African work derives, referred to the Scourian and Laxfordian 'complexes'. But as the authors have pointed out 'complex' can be used for diverse groups of rocks and it would seem that the term lacks that degree of particularity which something as impressive as the suite of rocks united in orogenesis demands of the imagination. To add the qualifying 'orogenic' to 'complex' overcomes this objection.

The term then approximately replaces the semi-geographical 'The Something (or Somewhere) orogenic belt' or the etymologically dubious 'Somethingides'. For practical purposes it would seem to be equivalent to the adjectival form ('Somewherean') advocated by Cahen \& Snelling (1966 p.21) but to have additional advantages.

One might wish, however, that the authors had gone further in giving examples of the usage they advocated. They might have tried out 'Laxfordian orogenic complex', or Macdonald's 'Watian orogenic complex' or 'the Kibaran orogenic complex'. One may ask whether these examples are acceptable and more meaningful than the adjectival form. This writer thinks these examples are in fact acceptable and probably more meaningful than 'Laxfordian', 'Watian' or 'Kibaran'. Again, if we attempt to add 'orogenic complex' to Clifford's 'Damaran' we find that it is inapplicable and hence heightens the meaning of 'Damaran' which, of course, Clifford (1967) referred to in full as the 'Damaran episode', although on Holmes' early map (reproduced facsimile complete with the original mistake as Allen \& Reedman's Fig.1) it was an 'orogenic belt'. And to settle for a 'Mozambique orogenic complex' might save the words Mozambique and Mozambiquian from degenerating into uselessness through the acquisition of various shades of meaning (orogeny? thermal event? epeirogenic event? geosyncline?).

I conclude, therefore, that 'orogenic complex' is an acceptable, useful term, only pleading that it should be remembered that the giving of a name does not necessarily imply that the suite of rocks referred to is any better understood than before it acquired its cognomen. In referring, for example, to the 'Mozambique orogenic complex' there is some danger in giving the impression that it is a well-defined, tightly knit group of rocks whose general character over a large area is well understood. This would be quite misleading. The usefulness of the term 'orogenic complex' would to some extent depend on the realization that it is mainly applicable to still abstruse metamorphic complexes. It would, for example, be inappropriate to refer to the Caledonian orogenic complex (of Europe).

While it would seem that 'orogenic complex' will be welcomed, the writers' second term 'orogenic assemblage' finds a less ready response. The present writer agrees with the authors' own verdict that it is a 'conceptual term' (p.295) and in attempting to apply it in practice he is at a loss to find a suitable example. It is indeed very difficult to visualize circumstances in which 'orogenic complex' might be used as a term for a complicated mass of diverse rocks characterized by gross structural conformity in which it would be possible to recognize those components which would allow the further distinction of an 'orogenic assemblage' in the sense visualized by the authors. Experience suggests that it is as much as can be expected that the 'orogenic complex' should be recognized, or. in less complex terrains, that conventional lithostratigraphic units should be discerned. Conversely it is to be supposed that if the 'detailed sedimentological and geochronological studies [which] may be necessary in order to recognize the post-orogenic sediments of a particular cycle' (p.295) were successfully carried out there would be no need to use the proposed terms,

The authors are probably unit in the Pre-Carnbrian of It in saying that the 'Sequence' is the most widely mapped adding up to an Orogenic As 3 mblage comes to mind.

These objections, however, should not be allowed to prevent the term 'Orogenic Complex' which they advocated from being given serious consideration. 


\section{REFERENCES}

CAHEN, L. \& SNELLING, N. J. 1966. The Geochronology of equatorial Africa. North Holland Publishing Co., Amsterdam.

CLIFFORD, T. N. 1967. The Damaran episode in the Upper Proterozoic-Lower Palaeozoic structural history of southern Africa. Spec. Pap. geol. Soc. Am., 92.

HEPWORTH, J. V. \& MACDONALD, R. 1966. Orogenic belts of the northern Uganda basement. Nature, Lond., 210, 726-727.

HOLMES, A. The sequence of Pre-Cambrian orogenic belts in south and central Africa. Intern. Geol. Congr., 18th, London, 1948. Pt. 14, 254-269.

SUTTON, J. \& WATSON, J. 1951. The pre-Torridonian metamorphic history of the Loch Torridon and Scourie areas in the north-west Highlands, and its bearing in the chronological classification of the Lewisian. $Q$. Jl geol. Soc. Lond., 106, $241-308$.

INSTITUTE OF GEOLOGICAL SCIENCES,

JOHN VORD HEPWORTH.

PHOTOGEOLOGICAL UNIT,

5, PRINCES GATE, LONDON, S.W.7.

19 th November, 1968.

SIR,-Dr. Hepworth's comments on our proposals concerning stratigraphic nomenclature are most welcome. In view of Dr. Hepworth's long experience in studying and interpreting the complex stratigraphy and tectonics of orogenic belts in East Africa, his conclusion that the term 'orogenic complex' is an acceptable and useful term is encouraging.

We disagree with Dr. Hepworth that it would be inappropriate to refer to the Caledonian Orogenic Complex (of Europe). This is, perhaps, not as necessary as with the older belts, but Phanerozoic orogens are just as readily divisible into torogenic complexes', 'orogenic assemblages' and 'sequences' as those in the Pre-Cambrian.

Dr. Hepworth finds the term 'orogenic assemblage' less useful than 'orogenic complex' and believes the term to have little practical application. We agree that the term 'orogenic assemblage' has disadvantages as a formal stratigraphic unit, the main one being that its definition is not based on purely objective criteria as are those of the 'orogenic complex' and the 'sequence'. As we originally stressed, it is a conceptual term. For this reason it could be argued that 'orogenic assemblage' should remain a convenient descriptive term for a part of the 'orogenic complex', the terms 'sequence' and 'orogenic complex' being the formal tectonostratigraphic units. However. whether used formally or informally, we believe the term to be a useful one in grouping together 'sequences', and two examples from areas where we have ourselves undertaken field mapping are given below.

Prof. W. Q. Kennedy first recognised the presence of an orogenic belt along the coast of West Africa and suggested that it was Pan-African in age (i.e. $\pm 550 \mathrm{~m} . y$.$) . Later work$ has proved its extent from the Rio de Oro southwards to Liberia. It has no single name: Sougy (1962) suggested the Mauritanides for the northern part, which he believed to be Hercynian, and Allen (in press) suggested Rokelides for the southern part, which is PanAfrican in age. Perhaps the term Rokel Orogenic Complex might be adopted for it. Excluding the intrusive rocks, the complex consists of three components: the refoliated basement of south-west Rio de Oro represented by the Kasila Group in Sierra Leone, the folded and metamorphosed geosynclinal rocks, a few examples of which are the Serie de Faleme in Senegal, the Serié de M'Bout in Mauritania and the Rokel River Group in Sierra Leone; and finally the molasse, which lies unconformably on the geosynclinal rocks. Examples of the latter are the Taban Formation in Sierra $\mathrm{H}^{\prime}$ ' ne and Guinea and its probable correlative, the Serić de Youkounkoun, also in Guin : In our definition both the geosynclinal rocks and the molasse comprise the 'oroget $\Sigma$ assemblage': thus, taking Sierra Leone as an example, the Rokel River Group and thee Taban Formation belong to it. They are separated by an unconformity and are, therefore, representative of two sequences. 
The so-called 'Karagwe-Ankole System' of south-western Uganda consists of at least two sequences, as does the 'Système de l'Urundi' or 'Burundian' of Rwanda. In Rwanda the lower sequence comprises the Serie(s) Inferieure(s) and the Serie de Byumba and the upper sequence, the Serie de Mijove (Gerards \& Lepersonne, 1964). The unconformity which separates the two sequences can be traced from Rwanda into the Kabale syncline in Kigezi, Uganda. Adopting the authors' terminology, the two sequences would represent the uneroded parts of the Kibaran Orogenic Assemblage in Uganda and Rwanda, the Kibaran Orogenic Complex in the same area including refoliated gneisses of the Kibali (Buganda-Toro) Orogenic Complex and the Rusizi Orogenic Complex which underlie the Kibaran Orogenic Assemblage and crop out as domal inliers.

Finally we would like to add a word of apology to Dr. J. V. Hepworth for having referred to him in our original paper as Dr. J. E. Hepworth.

\section{REFERENCES}

ALLEN, P. M. In press. The geology of part of an orogenic belt in Sierra Leone, West Africa. Geol. Rdsch., 58, 588-619.

GERARDS, J. \& LEPERSONNE, J. 1964. La stratigraphie du Burundien dans le nordest de Rwanda et les regions avoisinantes. Bull. Serv. géol. Repl. Rwandaise, 1. $13-31$.

SOUGY, J. 1962. West African Fold Belt. Bull. geol. Soc. Am., 73, 871-875.

\section{INSTITUTE OF GEOLOGICAL SCIENCES, 5 PRINCE'S GATE, LONDON S.W.7.}

P. O. BOX 71,
MBARARA,
UGANDA.

19th December, 1968.
P. M. ALLEN.

A. J. REEDMAN.

\section{WILLIAM SMITH'S LAST GEOLOGICAL EXCURSION}

SIR,-The last days of William Smith at the house of his friends, the Bakers of Northampton, were recorded by George Baker (1839), who related that the day after his arrival (a week before his death) 'we drove about thirty miles ... in a direction suggested by himself, to examine a point of doubtful stratification.' Baker also noted that the following day 'he walked with us nearly two miles, to see some fossil bones', perhaps at someone's house, as it appears from the sequel that this did not count as a geological excursion. The following day Smith was taken ill and he died five days later on 28 August after Baker had fetched Smith's nephew, Professor John Phillips, from the British Association meeting at Birmingham.

When Phillips' Memoirs of William Smith were published early in 1844 the author sent an inscribed copy to Baker, which I chanced to buy some time ago. With this copy is the draft (dated 11 March 1844) of a letter which Baker sent, or intended to send, to Phillips in acknowledgement, and which throws light on Smith's last excursion. Phillips $(1844$, p. 93$)$ had recounted a journey undertaken on foot in company with his uncle from Lincolnshire to Oxfordshire in the winter of 1819-20, and described how 'From this point (Wellingborough) we resumed our geological proceedings on foot, and passing by Irchester, Woolaston and Boziate, traversed in the next hills the oolite, the forest marble, the cornbrash, and an outlier of Kelloway's rock. The road up Boziate Hill was mantled with fossiliferous stone, some of which obtained from the hill-top was believed to be Kelloway's rock, and was found to contain Ammonites sublaevis and other fossils. A fine specimen of this ammonite was here laid by a particular tree on the road side, as it 